\title{
Performance Evaluation and Response of Yield Components and Yield of Bread Wheat to NPK Fertilizers at Hidebu Abote District of North Shewa Zone, Oromia
}

\author{
Abreham Feyisa*, Abera Donis, Dereje Girma \\ Fitche Agricultural Research Center, Oromia, Ethiopia \\ Email address: \\ abrehamfeyisa@gmail.com (A. Feyisa) \\ ${ }^{*}$ Corresponding author \\ To cite this article: \\ Abreham Feyisa, Abera Donis, Dereje Girma. Performance Evaluation and Response of Yield Components and Yield of Bread Wheat to \\ NPK Fertilizers at Hidebu Abote District of North Shewa Zone, Oromia. Plant. Vol. 8, No. 2, 2020, pp. 31-36. \\ doi: $10.11648 /$ j.plant.20200802.12
}

Received: May 20, 2020; Accepted: June 1, 2020; Published: June 23, 2020

\begin{abstract}
A field experiment was carried out on nitisols of Hidebu Abote district, North Shewa Zone, Oromia where wheat production is severely constrained by lack of an appropriate rate and types of fertilizer recommendation to evaluate wheat crop response to NPK fertilizer application. Fifteen NPK nutrients levels were considered and applied as treatments along with control (no fertilizer) at yaya Deka Bora peasant association were arranged in randomized complete block design (RCBD) with three replications at two farmers field. The ANOVA result indicated that plant height $(\mathrm{PH})$, above ground biomass yield (AGBMY), straw yield (SY), Thousand grain weight (TGW), grain yield (GY) and harvest index (HI) of bread wheat showed significant $(\mathrm{P} \leq 0.05)$ response to the NPK fertilizer application at both sites. The highest AGBMY (13.61 and 12.46 tons ha $\left.{ }^{-1}\right)$, SY $\left(8.13\right.$ and 7.33 tons ha $\left.{ }^{-1}\right)$ and GY (5475.00 and $\left.5414.33 \mathrm{~kg} \mathrm{ha}^{-1}\right)$ were recorded with the application of 69:30:20 NPK fertilizer combination at (site 1 and site 2) respectively and the lowest were recorded on control treatments. However the highest PH (103.8 and $97.27 \mathrm{~cm})$ at site 1 and site 2 was recorded respectively with the application of 92:10:20 NPK nutrients combinations. Both the statically and economical analysis showed that 69:30:20 NPK kg ha ${ }^{-1}$ of fertilizer application results in higher yield and economically profitable for bread wheat production in the study area. However further research experiment with multi locations, cropping seasons and different bread wheat cultivar have to be required in order to give best conclusive recommendation for the farmers.
\end{abstract}

Keywords: Bread Wheat, NPK Fertilizer, Nitisols, Grain Yield and Economic Benefit

\section{Introduction}

Wheat (Triticum aestivum L.) is the most important among all cereals used as a food grain in the world. Ethiopia is one of the largest wheat producing countries in the Sub-Saharan Africa [4]. However, Ethiopian wheat yields have been consistently well below the East African and world average yields, indicating low productivity of the crop [19]. The central highlands of Ethiopia are historically an important wheat growing region. In this region, wheat ranks second in total area, production and market demand after tef (Eragrostis tef) [7] and is produced across a range of soil conditions, particularly on well-drained highly-weathered reddish-brown soils (Nitisols) and poorly drained heavy dark clay soils (Vertisol) $[2,22]$. Despite the significant area of wheat production in Ethiopia, the mean national wheat yield of $1.3 \mathrm{t} \mathrm{ha}^{-1}$ is $24 \%$ below the mean yield for Africa and $48 \%$ below the global mean yield [11]. The national average yield of the crop is estimated at 2.74 tons $\mathrm{ha}^{-1}$ [7], which is very low, compared to the world's average yield of 3.09 tons $\mathrm{ha}^{-1}$ [10].

The applications of fertilizers contributed to the rise in production and enhanced per hectare yield. Wheat contributes $40 \%$ to the world food demand. It is also a significant part of proteins and carbohydrates intake [5].

The availability of nutrients to the plant will depict its yield and growth rate. Moreover, the application of vital nutrients in fertilizer form has positive impacts on the 
sustainable production of wheat [21]. The three most commonly required and widely used nutrients in agriculture are nitrogen $(\mathrm{N})$, phosphorus $(\mathrm{P})$, and potassium $(\mathrm{K})$ with a growing world population, food security has become increasingly more important. As potassium (K) is the third most essential nutrient element next to $\mathrm{N}$ and $\mathrm{P}$ for plant nutrition and It plays significant roles in the physiological processes of protein formation [15, 18] and Potassium fertilization is frequently associated with improved crop quality as well as better handling and storage properties. Plants deficient in potassium are stunted and develop poor root systems. Thus, due to this low level of $\mathrm{K}$ in the soils negative effects on crop yield and quality are observed in some parts of Ethiopia [1, 17]. As repeated cropping system of cereal crops used it causes rapid exhaustion of vital nutrients from soil, which ultimately cause poor soil fertility. The increase in production by enhancing soil fertility is a major challenge. If the nutrients deplete after the crop harvest, the soil fertility will go down and will create environmental stress in soil. Though, the application of fertilizers (NPK) is essential to restore the soil nutrients and to reduce the yield gap [6].

Replenishing soil fertility is the primary biophysical requirement for increasing food production in sub-Saharan Africa countries [19]. However, in Ethiopia, potassium (K) status of agricultural soils is generally found to be adequate for crop production, while a few studies show severely deficient soil $\mathrm{K}$ levels [9, 14]. In addition there has been a long established understanding, that Ethiopian soils are rich in potassium and believed to contain enough or sufficient quantity of the $\mathrm{K}$ nutrient thus there is no need for the application of this nutrient [8]. Fixation of $\mathrm{K}$ is correlated with the percentage of clay and is highest in Vertisol. Potassium fixation is enhanced by the presence of smectite and amorphous materials. The limited response of crops to applied $\mathrm{K}$ and the often high levels of exchangeable $\mathrm{K}$ found in most Ethiopian soils as a general and in the study area as particular have led researchers, development agents and policy maker to conclude that the $\mathrm{K}$ fertilization need in these soils is minimal. However, continuous cropping, in which fertilizer responsive varieties and improved management practices are used, results in $\mathrm{K}$ mining from the soil.

Though some researches which are focused on acid severity characterization, lime rates, acid tolerant varieties for cereals and feeds are conducted, the appropriate rate of potassium fertilizer in combination with NP fertilizer on cereal crops in general and in that of wheat crop in particular is not yet known.

Hence, the study was conducted with the objective of evaluating the effect of different NPK fertilizers level combinations on the yield and yield components of Wheat crop grown on the nitisols of the study area.

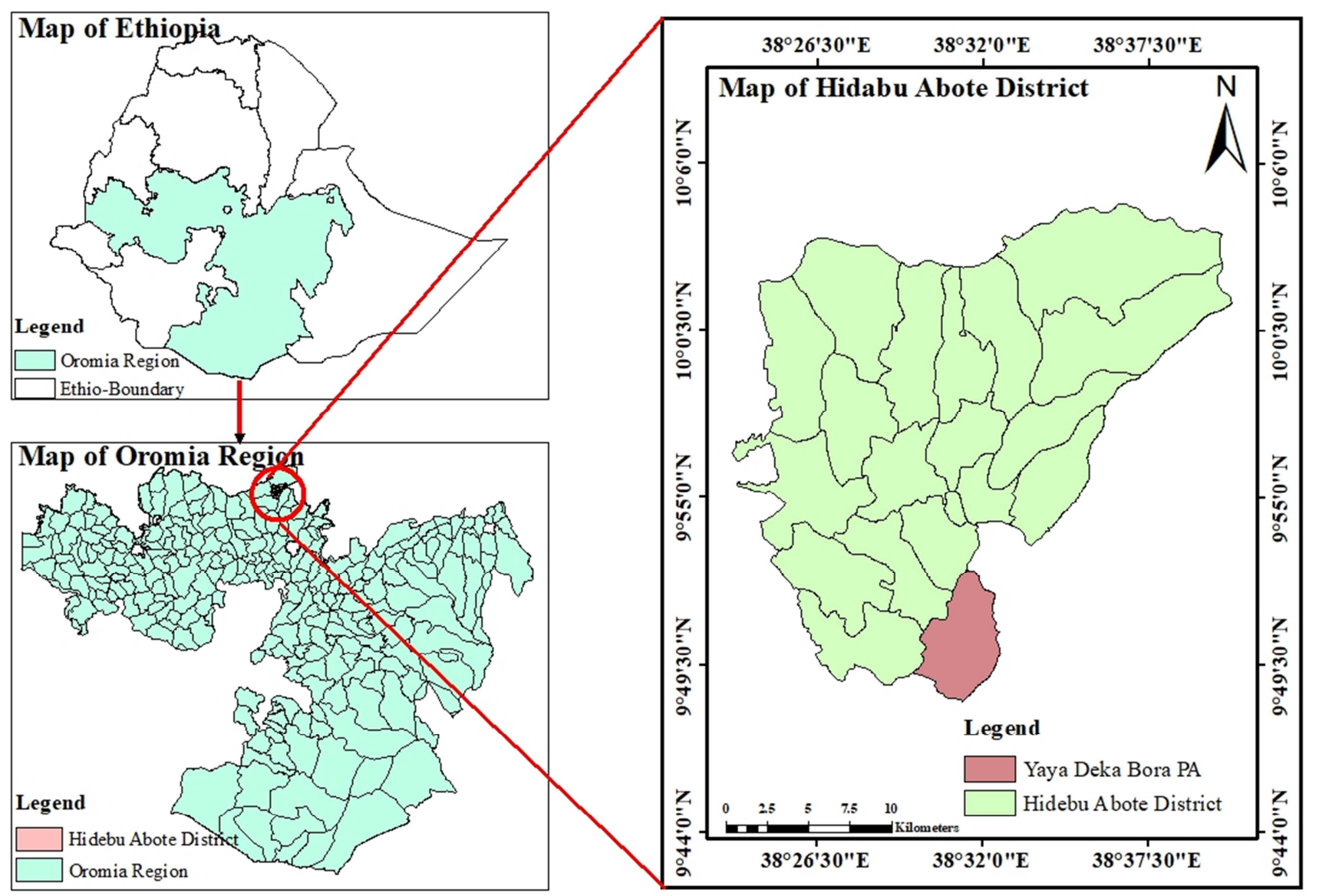

Figure 1. Map of the study area. 


\section{Materials and Methods}

\subsection{Study Area Description}

The experiment was conducted in 2016/17 cropping season on the highlands of Hidebu Abote District which is located in the North Shewa Zone of Oromia Region, Central Ethiopia. The district located at $09^{\circ} 44^{\prime} 0^{\prime \prime}$ to $10^{\circ} 6^{\prime} 0^{\prime \prime} \mathrm{N}$ and $38^{\circ} 26^{\prime} 30^{\prime \prime}$ to $38^{\circ} 37^{\prime} 30^{\prime \prime} \mathrm{E}$ with an average altitude of 1850 $\mathrm{m}$ above sea level. The mean annual rainfall of the area is about $971 \mathrm{~mm}$ that usually starts at about the end of March and ends in early November with the peak in August. The mean annual temperature of the area is $15.4^{\circ} \mathrm{C}$ and ranges from 9.7 to $21{ }^{\circ} \mathrm{C}$. The study site was located at Yaya Deka Bora peasant association. The dominant soil types in the Hidebu Abote highlands are mainly Nitisols and vertisol.

\subsection{Experimental Design and Procedures}

The experiment was conducted in Randomized Complete Block Design (RCBD) with three replications. The net plot size of was $3 \mathrm{~m} \times 4 \mathrm{~m}$. Fifteen fertilizer levels with one control plot (no fertilizer) were included as factors under study. The treatments comprised of; $\mathrm{T} 1=0-0-0$ (NPK), $\mathrm{T} 2=23-0-0$ (NPK), T3=46-0-0 (NPK), T4= 69-0-0 (NPK), $\mathrm{T} 5=92-0-0 \quad(\mathrm{NPK}), \quad \mathrm{T} 6=0-10-20 \quad(\mathrm{NPK}), \quad \mathrm{T} 7=23-10-20$ (NPK), T8=46-10-20 (NPK), T9=69-10-20 (NPK), T10=9210-20 (NPK), T11=69-10-0 (NPK), T12=69-20-0 (NPK), $\mathrm{T} 13=69-30-0$ (NPK), T14=69-30-10 (NPK), T15=69-30-20 (NPK) and T16=69-30-30 (NPK) $\mathrm{kg} \mathrm{ha}^{-1}$. The source of Nitrogen, phosphorous and potash was urea $(46 \% \mathrm{~N})$, Triple Super Phosphate $\left(46 \% \mathrm{P}_{2} \mathrm{O}_{5}\right)$ and potassium chloride $(60 \%$ $\mathrm{K}_{2} \mathrm{O}$ or $50 \% \mathrm{~K}$ ), respectively.

The improved bread wheat variety (HAR 3116) was used as a test crop with the recommended seed rate of $150 \mathrm{~kg} \mathrm{ha}^{-1}$ for all treatments uniformly. This improved bread wheat variety (HAR 3116), which is a high yielding variety widely grown in the wheat crop production belt highlands in the central part of the country as well as in the study area and all management practices were done. Land preparation and plowing, weeding, pesticide application and other agronomic management were carried out as per the recommendation for wheat crop production.

\subsection{Data Collection}

Plant height was determined by measuring the length of the plants from the ground level to the top of the spike just before physiological maturity. At physiological maturity, the plants were harvested close to the ground level by hand; air dried in an open dry environment and total biomass was determined by weighing the total biomass (straw and grain) as well as thousands grain weight also determined from thousand seeds counted per treatments and replications using sensitive balance.

\subsection{Data Analysis}

The data on crop yield and yield related traits were subjected to analysis of variance (ANOVA) using (Genstat, 18th edition) software and the statistical procedures described by [12]. The least significant difference (LSD) was used for comparing the means of wheat yields and crop response obtained with the different rates of NPK applications.

\subsection{Partial Budget Analysis}

In this study the partial budget analysis was done considering all variable costs and all benefits (straw and grain yield). Variable costs are costs of fertilizers which are used for fertilizer combination, application costs for fertilizer and cost of transport. The fertilizer cost was calculated for the cost of each fertilizers of DAP (18.45 ETB $\left.\mathrm{kg}^{-1}\right)$, Urea (14.5 ETB $\left.\mathrm{kg}^{-1}\right)$, potassium chloride $\left(15 \mathrm{Birr} \mathrm{kg}^{-1}\right)$ and. the cost of application and transport was 90 ETB $100 \mathrm{~kg}^{-1}$ of fertilizer and the average open market price of straw yield and wheat grain yield in the district market at time of harvesting was $9.50 \mathrm{ETB} \mathrm{kg}^{-1}$.

\section{Results and Discussions}

Yield Components and Yield Response of Wheat to NPK Fertilizers Application

Plant height $(\mathrm{cm})$ : The analysis of variance showed that plant height was significantly affected by different levels of NPK fertilizer application at both sites (Table 1). The highest plant height $(103.8 \mathrm{~cm})$ and $(97.27 \mathrm{~cm})$ was recorded when 92:10:20 kg ha ${ }^{-1}$ NPK fertilizer rate was applied at both sites while the lowest plant height was recorded from treatment where no fertilizer was applied. The result indicated that height increased linearly with each consecutive increase in NPK fertilizers which was attributed to the gradual increase in plant height. This linear increment might be due to in fact that an increase in NPK fertilizer levels favors the vegetative growth and simultaneously boost the nutrient use efficiency of other nutrients in the soil by crops and thereby attribute a great role for the normal growth and developments of plants. This result agrees with [3].

Biomass yield (tons $\mathrm{ha}^{-1}$ ): Above ground biomass of bread wheat was also highly significant affected by NPK fertilizer rates application at both site of the study area. The maximum biomass yield (13.61 tons $\mathrm{ha}^{-1}$ ) was recorded on 69:30:20 NPK which statistically at par with T5, T10, T12, T13, T14 and $\mathrm{T} 16$ at site 1 and similarly (12.46 tons ha ${ }^{-1}$ ) was recorded on 69:30:20 NPK which statistically at par with T10 to T16 at site 2; while the lowest was on no fertilizers application. This might be due to synergetic effect of highest dose of NP fertilizer application with potassium only up to $20 \mathrm{~K}$ favors the nutrient use efficiency and vegetative growth of crops and above these levels the result began to decrease in yield. This result is in agreement with [13] who reported the highest biological yield of 7,662 and $10,497 \mathrm{~kg} \mathrm{ha}^{-1}$ at two different sites in Akaki with the application of 30:26 NP fertilizers which also indicated that the yield began to decrease above this level of fertilizer combinations.

Straw yield (tons $\mathrm{ha}^{-1}$ ): The analysis of variance result showed that straw yield were significantly $(\mathrm{P}<0.05)$ affected 
by NPK fertilizer levels at both locations (site 1 and site 2). The maximum straw yield ( 8.13 tons ha $\left.{ }^{-1}\right)$ at site 1 on $\mathrm{T} 5$ and ( 7.33 tons $\mathrm{ha}^{-1}$ ) at site 2 on T10 and T14 were recorded whereas the minimum was recorded with no fertilizer application. The result was in agreement with [13] which conclude that the highest straw yield $\left(4847 \mathrm{~kg} \mathrm{ha}^{-1}\right.$ and 10968 $\mathrm{kg} \mathrm{ha}^{-1}$ ) were obtained on the interaction of $30: 26$ and 30:39 PK kg ha ${ }^{-1}$ at Akaki and Cheffe Donsa, respectively.

Table 1. Bread wheat yield components response to NPK fertilizers application at two different locations.

\begin{tabular}{|c|c|c|c|c|c|c|}
\hline \multirow{2}{*}{ Treatments NPK } & \multicolumn{3}{|l|}{ Site 1} & \multicolumn{3}{|l|}{ Site 2} \\
\hline & PH (cm) & AGBMY (tons ha ${ }^{-1}$ ) & SY (tons ha ${ }^{-1}$ ) & PH (cm) & AGBMY (tons ha ${ }^{-1}$ ) & SY (tons ha ${ }^{-1}$ ) \\
\hline T1 $(0: 0: 0)$ & $78.30^{\mathrm{g}}$ & $3.71^{\mathrm{g}}$ & $1.88^{\mathrm{d}}$ & $63.67^{\mathrm{g}}$ & $4.16^{\mathrm{h}}$ & $2.54^{\mathrm{f}}$ \\
\hline T2 (23:0:0) & $82.73^{\mathrm{fg}}$ & $5.60^{\mathrm{fg}}$ & $3.48^{\mathrm{cd}}$ & $69.13^{\mathrm{fg}}$ & $5.10^{\text {gh }}$ & $2.97^{\mathrm{ef}}$ \\
\hline T4 (69:0:0) & $96.20^{\mathrm{cd}}$ & $8.55^{\mathrm{c}-\mathrm{f}}$ & $5.44^{\mathrm{abc}}$ & $86.87^{\text {bcd }}$ & $7.36^{\mathrm{ef}}$ & $4.26^{\text {cde }}$ \\
\hline T5 (92:0:0) & $100.33^{\mathrm{abc}}$ & $10.42^{\mathrm{a}-\mathrm{d}}$ & $6.60^{\mathrm{abc}}$ & $91.13^{\mathrm{abc}}$ & $9.67^{\mathrm{cd}}$ & $5.80^{\mathrm{abc}}$ \\
\hline T6 $(0: 10: 20)$ & $83.27^{\mathrm{f}}$ & $7.00^{\mathrm{d}-\mathrm{g}}$ & $4.89^{\mathrm{a}-\mathrm{d}}$ & $69.2^{\text {fg }}$ & $4.91^{\mathrm{h}}$ & $2.89^{\mathrm{ef}}$ \\
\hline T8 (46:10:20) & $92.13^{\mathrm{de}}$ & $9.86^{\mathrm{b}-\mathrm{e}}$ & $6.46^{\mathrm{abc}}$ & $85.93^{\mathrm{cd}}$ & $8.36^{\text {de }}$ & $5.14^{\text {bcd }}$ \\
\hline T9 (69:10:20) & $96.73^{\mathrm{cd}}$ & $9.67^{\mathrm{b}-\mathrm{e}}$ & $5.81^{\mathrm{abc}}$ & $89.53^{\mathrm{a}-\mathrm{d}}$ & $10.16^{\mathrm{bc}}$ & $6.07^{\mathrm{ab}}$ \\
\hline $\mathrm{T} 10(92: 10: 20)$ & $103.80^{\mathrm{a}}$ & $12.29^{\mathrm{ab}}$ & $7.48^{\mathrm{ab}}$ & $97.27^{\mathrm{a}}$ & $12.16^{\mathrm{a}}$ & $7.33^{\mathrm{a}}$ \\
\hline T11 (69:10:0) & $97.60^{c}$ & $9.52^{\mathrm{b}-\mathrm{e}}$ & $5.35^{\mathrm{a}-\mathrm{d}}$ & $94.87^{\mathrm{ab}}$ & $11.24^{\mathrm{ab}}$ & $7.25^{\mathrm{a}}$ \\
\hline T12 (69:20:0) & $99.20^{\mathrm{abc}}$ & $10.42^{\mathrm{a}-\mathrm{d}}$ & $6.08^{\mathrm{abc}}$ & $92.27^{\mathrm{abc}}$ & $11.28^{\mathrm{ab}}$ & $6.90^{\mathrm{a}}$ \\
\hline T13 (69:30:0) & $103.33^{\mathrm{ab}}$ & $10.20^{\mathrm{a}-\mathrm{e}}$ & $5.53^{\mathrm{abc}}$ & $92.87^{\mathrm{abc}}$ & $11.45^{\mathrm{ab}}$ & $6.69^{\mathrm{ab}}$ \\
\hline T14 (69:30:10) & $99.87^{\mathrm{abc}}$ & $11.84^{\mathrm{abc}}$ & $6.92^{\mathrm{abc}}$ & $94^{\mathrm{abc}}$ & $12.19^{\mathrm{a}}$ & $7.33^{\mathrm{a}}$ \\
\hline T15 (69:30:20) & $102.47^{\mathrm{ab}}$ & $13.61^{\mathrm{a}}$ & $8.13^{\mathrm{a}}$ & $93.87^{\mathrm{abc}}$ & $12.46^{\mathrm{a}}$ & $7.05^{\mathrm{a}}$ \\
\hline $\operatorname{LSD}(0.05)$ & 4.68 & 1.99 & 1.93 & 4.53 & 0.82 & 0.93 \\
\hline CV (\%) & 3.0 & 12.7 & 20.1 & 3.2 & 5.4 & 10.4 \\
\hline
\end{tabular}

Means with the same letter in columns are not significantly different at 5\% level of significance's; PH= Plant height, AGBMY= above ground biomass yield, $\mathrm{SY}=$ Straw yield, LSD $=$ Least significant differences at $5 \%$ and $\mathrm{CV}(\%)=$ Coefficient of variation.

Thousand Grain Yield (gm): The analysis of variance showed that thousand grain weight was significantly affected only at site 2 but not at site 1 (Table 2). The maximum thousand grain weight (35.07 gm) was recorded on T10 (92:10:20 NPK) whereas the minimum was on T6 (0:10:20
NPK) fertilizer application a site 2 . This might be due to in fact that higher dose of nitrogen fertilizer $(92 \mathrm{~N})$ availability in treatments combination attributes for higher vegetative growth and development thereby an increase of maximum grain size and thousand grain weight.

Table 2. Bread wheat yield components and yield response to NPK fertilizers application at two different locations.

\begin{tabular}{|c|c|c|c|c|c|c|}
\hline \multirow{2}{*}{ Treatments NPK } & \multicolumn{3}{|l|}{ Site 1} & \multicolumn{3}{|l|}{ Site 2} \\
\hline & TGW (gm) & GY $\left(\mathrm{kg} \mathrm{ha}^{-1}\right)$ & HI (\%) & TGW (gm) & GY $\left(\mathrm{kg} \mathrm{ha}^{-1}\right)$ & HI (\%) \\
\hline $\mathrm{T} 1(0: 0: 0)$ & 32.00 & $1830.75^{\mathrm{h}}$ & $49.47^{\mathrm{a}}$ & $30.00^{\mathrm{ab}}$ & $1617.00^{\mathrm{h}}$ & 39.87 \\
\hline T2 (23:0:0) & 31.07 & $2116.67^{\mathrm{h}}$ & $38.71^{\mathrm{abc}}$ & $30.40^{\mathrm{ab}}$ & $2131.75^{\mathrm{gh}}$ & 42.32 \\
\hline T3 (46:0:0) & 32.67 & $2341.67^{\mathrm{h}}$ & $34.73^{\mathrm{abc}}$ & $29.73^{\mathrm{ab}}$ & $2381.25^{\mathrm{g}}$ & 37.44 \\
\hline T4 (69:0:0) & 35.20 & $3116.92^{\mathrm{g}}$ & $36.42^{\mathrm{abc}}$ & $33.60^{\mathrm{ab}}$ & $3096.58^{\text {ef }}$ & 42.08 \\
\hline T5 (92:0:0) & 32.93 & $3816.67^{\mathrm{ef}}$ & $36.71^{\mathrm{abc}}$ & $32.80^{\mathrm{ab}}$ & $3865.67^{d}$ & 40.00 \\
\hline T6 $(0: 10: 20)$ & 30.67 & $2108.33^{\mathrm{h}}$ & $32.47^{\mathrm{bc}}$ & $27.60^{\mathrm{b}}$ & $2011.00^{\mathrm{gh}}$ & 41.19 \\
\hline T8 (46:10:20) & 35.76 & $3397.50^{\mathrm{fg}}$ & $34.47^{\mathrm{abc}}$ & $32.13^{\mathrm{ab}}$ & $3220.33^{\mathrm{e}}$ & 38.95 \\
\hline T9 (69:10:20) & 35.73 & $3858.33^{\mathrm{ef}}$ & $41.41^{\mathrm{abc}}$ & $33.33^{\mathrm{ab}}$ & $4087.25^{\mathrm{d}}$ & 40.40 \\
\hline $\mathrm{T} 10(92: 10: 20)$ & 35.87 & $4806.92^{\mathrm{bc}}$ & $39.58^{\mathrm{abc}}$ & $35.07^{\mathrm{a}}$ & $4831.83^{b c}$ & 39.69 \\
\hline T11 (69:10:0) & 35.33 & $4166.67^{\mathrm{de}}$ & $45.29^{\mathrm{abc}}$ & $31.73^{\mathrm{ab}}$ & $3990.08^{d}$ & 35.54 \\
\hline T12 (69:20:0) & 32.26 & $4341.00^{\text {cde }}$ & $43.13^{\mathrm{abc}}$ & $31.33^{\mathrm{ab}}$ & $4381.25^{\mathrm{cd}}$ & 38.84 \\
\hline T13 (69:30:0) & 33.73 & $4664.08^{\mathrm{bcd}}$ & $46.25^{\mathrm{abc}}$ & $31.20^{\mathrm{ab}}$ & $4759.00^{\mathrm{bc}}$ & 41.64 \\
\hline T14 (69:30:10) & 34.27 & $4925.00^{\mathrm{abc}}$ & $41.66^{\mathrm{abc}}$ & $32.93^{\mathrm{ab}}$ & $4869.92^{\mathrm{abc}}$ & 39.96 \\
\hline LSD (0.05) & Ns & 340.1 & 9.31 & 3.73 & 310.1 & Ns \\
\hline CV $(\%)$ & 7.2 & 5.6 & 14.2 & 7.1 & 5.1 & 10.2 \\
\hline
\end{tabular}

Means with the same letter in columns are not significantly different at $5 \%$ level of significance's; TGW= Thousand grain weight, GY=Grain yield, HI= Harvest, LSD $=$ Least significant differences at $5 \%$ and CV $(\%)=$ Coefficient of variation, Ns=Non significant.

Grain Yield $\left(\mathrm{kg} \mathrm{ha}^{-1}\right)$ : The analysis of variance showed that the grain yield of bread wheat was highly significantly affected by NPK fertilizers application rate. The highest grain yield $\left(5475 \mathrm{~kg} \mathrm{ha}^{-1}\right)$ and $\left(5414.33 \mathrm{~kg} \mathrm{ha}^{-1}\right)$ was obtained at site 1 and site 2 respectively on the application of 69:30:20
NPK fertilizers while the lowest was on no fertilizer application on both site. The increase in yield trend from Table 2 showed increase in NPK resulted in increase of yield up to certain limited combination of NPK fertilizer. However, there was decrease in certain level especially above (69-30- 
20 NPK kg ha ${ }^{-1}$ ) which might be due to potassium interaction with $\mathrm{N}$ and $\mathrm{P}$ above this dose may negatively and counter affect the efficient use one nutrient on the other by the crops and results in yield reduction. The result was in agreement with [13] who reported the highest grain yield of $(4,797 \mathrm{~kg}$ $\left.\mathrm{ha}^{-1}\right)$ from application of $\left(30: 26 \mathrm{PK} \mathrm{kg} \mathrm{ha}^{-1}\right)$. The result is also in line with [16] who reported that 64:20:50 NPK produced the highest yield than that produced by all other fertilizer treatments and it increased grain yield by $30.5 \%$ over the control.

Harvest Index (\%): Harvest index was significantly affected at site 1 but not significantly influenced at site 2 . The highest HI (49.47\%) was recorded at site 1 on the control treatments which is statically at par with all treatments except T7 and T6 which also scored the lowest harvest index respectively (Table 2 ).

\section{Economic and Partial Budget Analysis}

Economic analysis conducted for using different level of NPK nutrient fertilizers for wheat crop production indicated that as (Table 3), significantly beneficial and the highest marginal rate of return $(6332.54 \%)$ was recorded on T11 (69:10:0) followed by (2018.44 and $1891.29 \%)$ on T5 and T15 respectively. However, the maximum net benefit (62639.65 ETB) was obtained with the application of 69:30:20 NPK (T15) followed by (57209.50 and 56625.35 $\mathrm{ETB})$ on $\mathrm{T} 10$ and $\mathrm{T} 14$ respectively.

Therefore, application of 69:30:20 NPK kg ha ${ }^{-1}$ of fertilizer in the production of bread wheat was more economically beneficial and feasible for farmers and other stakeholder as well as it was the best alternative option of fertilizer rate and type use for around Hidebu Abote district area with similar soil types and agro ecologies.

Table 3. Combined mean of Partial budget and economic analysis of NPK fertilizer application for wheat crop production.

\begin{tabular}{|c|c|c|c|c|c|c|c|c|c|c|c|c|}
\hline \multirow{2}{*}{$\begin{array}{l}\text { Treatments } \\
\text { NPK (kg/ha) }\end{array}$} & \multirow{2}{*}{$\begin{array}{l}\text { GY } \\
\text { (kg/ha) }\end{array}$} & \multirow{2}{*}{$\begin{array}{l}\text { SY } \\
\text { (kg/ha) }\end{array}$} & \multicolumn{2}{|c|}{ TFGB (ETB/ha) } & \multirow{2}{*}{$\begin{array}{l}\text { TGB } \\
\text { (ETB/ha) }\end{array}$} & \multirow{2}{*}{$\begin{array}{l}\text { Fert. } \\
\text { cost } \\
\text { (ETB) }\end{array}$} & \multirow{2}{*}{$\begin{array}{l}\text { App. } \\
\text { cost }\end{array}$} & \multirow{2}{*}{ TVC } & \multirow{2}{*}{$\begin{array}{l}\Delta T V C \\
\text { (ETB/ha) }\end{array}$} & \multirow{2}{*}{$\begin{array}{l}\text { NB } \\
\text { (ETB/ha) }\end{array}$} & \multirow{2}{*}{$\begin{array}{l}\Delta \mathrm{NB} \\
\text { (ETB/ha) }\end{array}$} & \multirow{2}{*}{$\begin{array}{l}\text { MRR } \\
(\%)\end{array}$} \\
\hline & & & GY & SY & & & & & & & & \\
\hline $\mathrm{T} 1=0: 00: 00$ & 1723.88 & 2210 & 17238.75 & 4088.50 & 21327.25 & 0.00 & 0 & 0 & 0 & 21327.25 & 21327.25 & 0 \\
\hline $\mathrm{T} 3=46: 00: 00$ & 2361.46 & 4225 & 23614.60 & 7816.25 & 31430.85 & 1450.00 & 90 & 1540 & 770 & 29890.85 & 3452.5 & 448.38 \\
\hline $\mathrm{T} 6=0: 10: 20$ & 2059.67 & 3890 & 20596.65 & 7196.50 & 27793.15 & 1522.50 & 81 & 1603.5 & 63.5 & $\mathrm{D}$ & & 0.00 \\
\hline $\mathrm{T} 4=69: 00: 00$ & 3106.75 & 4850 & 31067.50 & 8972.50 & 40040.00 & 2175.00 & 135 & 2310 & 706.5 & 37730.00 & 11540.35 & 1633.45 \\
\hline $\mathrm{T} 5=92: 00: 00$ & 3841.17 & 6200 & 38411.70 & 11470.00 & 49881.70 & 2900.00 & 180 & 3080 & 706.5 & 46801.70 & 14260.25 & 2018.44 \\
\hline $\mathrm{T} 8=46: 10: 20$ & 3308.92 & 5800 & 33089.15 & 10730.00 & 43819.15 & 2972.50 & 171 & 3143.5 & 63.5 & $\mathrm{D}$ & & 0.00 \\
\hline $\mathrm{T} 11=69: 10: 00$ & 4078.38 & 6300 & 40783.75 & 11655.00 & 52438.75 & 3097.50 & 180 & 3277.5 & 134 & 49161.25 & 8485.6 & 6332.54 \\
\hline T9=69:10:20 & 3972.79 & 5940 & 39727.90 & 10989.00 & 50716.90 & 3697.50 & 216 & 3913.5 & 636 & $\mathrm{D}$ & & 0.00 \\
\hline $\mathrm{T} 12=69: 20: 00$ & 4361.13 & 6490 & 43611.25 & 12006.50 & 55617.75 & 4020.00 & 225 & 4245 & 331.5 & 51372.75 & 4569.35 & 1378.39 \\
\hline $\mathrm{T} 10=92: 10: 20$ & 4819.38 & 7405 & 48193.75 & 13699.25 & 61893.00 & 4422.50 & 261 & 4683.5 & 438.5 & 57209.50 & 5836.75 & 1331.07 \\
\hline $\mathrm{T} 13=69: 30: 00$ & 4711.54 & 6110 & 47115.40 & 11303.50 & 58418.90 & 4942.50 & 270 & 5212.5 & 529 & $\mathrm{D}$ & & 0.00 \\
\hline $\mathrm{T} 14=69: 30: 10$ & 4897.46 & 7125 & 48974.60 & 13181.25 & 62155.85 & 5242.50 & 288 & 5530.5 & 318 & 56625.35 & 3418.95 & 1075.14 \\
\hline $\mathrm{T} 16=69: 30: 30$ & 5086.55 & 6450 & 50865.45 & 11932.50 & 62797.95 & 5842.50 & 324 & 6166.5 & 318 & $\mathrm{D}$ & & 0.00 \\
\hline
\end{tabular}

Note: $\mathrm{GY}=$ Grain Yield; $\mathrm{SY}=$ Straw Yield; TFGB=Total Farm field Gross Benefit; TGB=Total Gross Benefit; TVC=Total Variable Cost; $\Delta \mathrm{TVC}=\mathrm{Change}$ in Total Variable Cost; NB=Net Benefit; $\Delta \mathrm{NB}=$ Change in Net Benefit; $\mathrm{D}=$ Dominated; ETB=Ethiopian Birr; MRR= Marginal Rate of Return.

\section{Summary and Conclusions}

An experiment conducted for one cropping season over two site at Hidebu Abote district indicated that a biological yield and grain yield of bread wheat significantly response to NPK fertilizer application. Yield increase was observed at both locations with the combined use of these nutrients. Thus, it can be concluded that the combined use of N, P and $\mathrm{K}$ could be beneficial to enhance nutrient uptake and productivity of wheat up to certain limited and specified dose of nutrient combination in the study area.

The result of the study indicated that both statistically and economically as the application and use of 69:30:20 NPK kg $\mathrm{ha}^{-1}$ of fertilizer rate is more profitable and high yielder as compared to other fertilizer rate combination for the production of bread wheat. This should be demonstrated and scale ups to the farmers in the area and it would help for dissemination through the extension System so as to make the results usable in the future.
However, definite recommendation may not be drawn from this research result, as the present result came from single experiment involving one cultivar item, cropping season and few locations. Therefore, it is advisable to undertake further research across soil types, season and locations involving others best performing cultivar to draw sound recommendation on a wider scale and for longer duration and variable cropping systems.

\section{Acknowledgements}

The first and foremost gratitude and praise goes to ours almighty GOD, who helped us in every aspect of our life, including in the completion of this research work.

Next the authors highly acknowledge the Agricultural Transformation Agency (ATA) for sponsoring this experiment project work. Special thanks also goes to Fitche Agricultural Research Center via Oromia Agricultural Research Institute for their great collaborative facilitation of the required budget for the implementation of an experiment 
with funding project organization.

The last but not the least the author would like to thanks those farmers and their family who permit us their farm field for us to conduct an experiment. We also extend our thanks for Mr. Endale Bededa and all staff members of Fitche Agricultural Research Center for their unreserved technical and material support.

\section{References}

[1] Abiye, A., T. Mamo, D. Peden, and M. Diedhiou, M. 2004. Participatory on Farm Conservation Tillage Trial in the Ethiopian highland Vertisols: The Impact of Potassium Application on Crop Yields. Experimental Agriculture 40 (3): 369-379.

[2] Asamenew, G. 1991. A Study of the Farming Systems of Some Ethiopian Highland Vertisols Areas (draft report). ILCA (International Livestock Centre for Africa), Addis Ababa, Ethiopia.

[3] Asmat Ullah Malik, Abdul Latif Malghani, A. Sattar, Fiaz Hussain, G. Abbas and J. Hussain. 2010. Response of Growth and Yield of Wheat to NPK Fertilizer. International science (Lahore). 24 (2), 185-189.

[4] Asfaw Negassa, Shiferaw, B., Koo, J., Sonder, K., Smale, M., Braun, H. J., GBegbelegbe, S., Zhe Guo., Hodson, D. P., Wood, S., Payne, T. and Abeyo, Bekele Geleta. 2012. The Potential for Wheat Production in Sub-Saharan Africa: Analysis of Biophysical Suitability and Economic Profitability Mexico. CIMMYT.

[5] Ayala Zavala, J. F., V. Vega Vega, C. Rosas Dom Inguez, H. Palafox Carlos, J. A. Villa Rodriguez, Md. Wasim Siddiqui, J. E. Davila Avina, and G. A. Gonzalez Aguilar. 2011. Agroindustrial potential of exotic fruit byproducts as a source of food additives. Food Research International 44 (7): 1866-74. doi: 10.1016/j.foodres.2011.02.021.

[6] Brummer, E Charles, Wesley T. Barber, Sarah M. Collier, Thomas S. Cox, Randy Johnson, Seth C. Murray, Richard T. Olsen, Richard C. Pratt, and Ann Marie Thro. 2011. Plant breeding for harmony between agriculture and the environment. Frontiers in Ecology and the Environment 9 (10): 561-8. doi: 10.1890/100225.

[7] CSA (Central Statistical Agency). 2018. Agricultural Sample Survey: Report on Area and Production of Major Crops. Vol. I. Addis Ababa, Ethiopia.

[8] Deressa, A., Bote, B. and Legesse, H. 2013. Evaluation of Soil Cations in Agricultural Soils of East Wellega Zone in the South Western Ethiopia. Science Technology and Art Research. J. 2: 10-17.

[9] EthioSIS (Ethiopian Soil Information System). 2015. http://www.ata.gov.et/highlighted-deliverables/ethiopian-soilinformation-system-ethiosis/. Accessed 15 March 2015.
[10] FAOSTAT (FAO Statistical Databases) 2012. Agricultural Production Statistics. http://www.fao.org/faostat. Accessed 15 March 2016.

[11] Gavian, S., and G. Degefa. 1996. The Profitability of Wheat Production in Ethiopia: The Case of Tiyo Woreda in Arsi Region. Ethiopian Journal of Agricultural Economics 1 (1): 38-62.

[12] Gomez, K. A., and A. A. Gomez. 1984. Statistical Procedures for Agricultural Research, 2nd Edition. John Wiley and Sons Inc., London, UK.

[13] Hillete Hailu, Tekalign. Mamo, and R. Keskinen. 2017. Response of Wheat (Triticum aestivum L.) to Phosphorus and Potassium Fertilization on Vertisols in Ethiopia's Central Highlands. International Potash Inistitute. Research Findings.

[14] Laekemariam, F. 2015. Soil Spatial Variability Analysis, Fertility Mapping and Soil Plant Nutrient Relations in Wolaita Zone, Southern Ethiopia. $\mathrm{PhD}$ Dissertation, Haramaya University, Ethiopia.

[15] Lakudzala, D. D., 2013. Potassium response in some Malawi soils. International Letters of Chemistry, Physics and Astronomy, 8 (2) (2013) 175-181.

[16] Molla Hadis, Gashaw Meteke and Wassie Haile. 2018. Response of bread wheat to integrated application of vermicompost and NPK fertilizers. African Journal of Agricultural Research. Vol. 13 (1), pp. 14-20.

[17] Pound, B. and Jonfa, E., 2005. Soil Fertility Practices in Wolaita Zone, Southern Ethiopia: Learning from Farmers. Farm Africa, Waterside press, London.

[18] Rehm, G. and Schmitt, M., 2002. Potassium for crop production. University of Minnesota Extension. (http://www.extension.umn.edu/distribution/cropsystems/DC6 794.html) Accessed on March 15, 2014.

[19] Sanchez Pedro. 2010. Tripling Crop Yields in Tropical Africa. Nature geo sciences, Vol 3, Commentary Focus. www.nature.com/nature geosciences.

[20] Schneider, K. and Anderson, L. 2010. Yield Gap and Productivity Potential in Ethiopian Agriculture: Staple Grains \& Pulses, Evans School Policy Analysis and Research (EPAR). University of Washington, EPAR Brief No. 98.

[21] Shaharoona, B., M. Naveed, M. Arshad, and Z. A. Zahir. 2008. Fertilizer Dependent Efficiency of Pseudomonads for Improving Growth, Yield, and Nutrient Use Efficiency of Wheat (Triticum aestivum L.). Applied Microbiology and Biotechnology 79 (1): 147-55. doi: 10.1007/s00253-0081419-0.

[22] Woldeab, A., T. Mamo, M. Bekele, and T. Ajema. 1991. Soil Fertility Management Studies on Wheat in Ethiopia. In: Gebre Mariam, H., D. G. Tanner, and Hulluka (eds.). Wheat Research in Ethiopia: A Historical Perspective. p. 112-144. IAR/CIMMYT, Addis Ababa, Ethiopia. 